\title{
Effectiveness of Watershed Management- Means Of Economical Development- A Case Study
}

\author{
Mr. Vishal P. Kumbhar ${ }^{1}$, Mrs. Vidula A. Swami ${ }^{2}$, Mrs. Sushma S. Kulkarni ${ }^{3}$ \\ ${ }^{1 \& 3}$ Department of Civil Engineering, K.E. Society's Rajarambapu Institute of Technology, Sakharale, Dist- \\ Sangli, Maharashtra State, India. \\ 2 Department of Civil Engineering, KIT's College of Engineering, Gokul Shirgaon, Dist- Kolhapur, \\ Maharashtra State, India.
}

\begin{abstract}
Water is the life-blood of the environment, without water no living beings can survive. Water plays unique role in development of all sectors in any economy of every country. Water is used for agricultural, domestic, industrial, power generation and other various purposes. But misuses of water resources cause widespread degradation of soil and disrupt the supply of potable water, generate massive economical loss. Hence it becomes necessary to harness the water resources available on Earth through the application of science and technology. This paper presents one such case study where large amount of rainwater is possible to direct to recharge ground water resources. Kaneri is a small village located at distance of $10 \mathrm{Kms}$. from Kolhapur city. It is planned to take such engineering and biological measures which will direct this extra runoff to ground water storage. The most significant feature of the work is that if such technologies are developed and adopted at larger scale in rural areas, it will prevent thousands of villages of the country from water supply by tankers. Moreover this will also help us for economical development of village people which mainly occurs due to water scarcity.
\end{abstract}

Keywords Watershed, Watershed management technique, Socio- economic survey, Water budgeting, Intercropping pattern, Farm pond, Gully plugs, Contour trench, Groundwater storage, Economical development.

\section{INTRODUCTION}

Rainwater, a scarce and critical resource for growing food and providing livelihood support for rural populations, is under threat particularly in the arid and semi-arid regions of the world. Rainfall in the semi-arid tropics (SAT) generally occurs in short torrential downpours. Most of this water is lost as run-off, eroding significant quantities of precious top soil. The current rainwater-use efficiency for crop production is low ranging from 30 to 45 percent; thus annually about $300-800 \mathrm{~mm}$ of seasonal rainfall goes unproductive, lost either as surface run-off or deep drainage. Generally, if the water availability in the region or state is less or equal to $1700 \mathrm{~m}^{3} /$ person / year it experiences periodic water stress and if the availability is $1000 \mathrm{~m}^{3} /$ person / year the state of region will be under water scarcity. The above norms reveal that northern part of India comes under water stress and southern parts of India experience water scarcity.

The economical development and management of villages in India is one of the most important factors for the growth of Indian economy. India is the agriculture based country. Agriculture contributes nearly onefifth of the gross domestic product in India.

Most of the villagers of these areas have agriculture as their primary occupation. The traditional agricultural practices mainly depended on monsoon rains. Generally monsoon rainfalls occur between June and September months. But in spite of sufficient rainfall, people have to depend upon tankers even for their domestic water supply in summer. This is mainly due to large runoff which is responsible for water loss as well as soil loss of the land. A raindrop, when flows along the slope, carries the loose soil along it. In this case the topmost layer of soil is lost rapidly. Due to high intensity rainfall, it is estimated that, more than 100 tons of soil is lost. By having soil and land management along with the water management thus developing watersheds, economical development of rural area is possible.

This paper gives case study of Kaneri village, which is $10 \mathrm{~km}$ away from Kolhapur city (Maharashtra). In Kaneri village, requirement of water for farming is very high but there is depletion of water resources. So reduce crop yield and income from agricultural activity is low. There is increasing demand of drinking water, food, and firewood for people and fodder for livestock. Peoples have to depend on supply of water by tankers. So it has become necessary to develop the means to storage of runoff and recharge ground water resources which are essentials for improving living standard of people. 


\section{CONCEPT OF WATERSHED}

A watershed can be defined as the drainage basin or catchment area of a particular stream or river. Simply put, it refers to the area from where the water to a particular drainage system, like a river or stream, comes from.

People and their environment are interdependent. Any change in the surrounding environment directly affects the people living therein. A degraded environment results in a degraded quality of life of the people. Thus efforts to reduce poverty and improve the standard of living of the people must aim at improving the environment they live in. Watershed development: watershed development refers to the conservation, regeneration and the judicious use of all the resources - natural (land, water, plants and animals) and human within a particular watershed.

\section{IMPORTANCE OF WATERSHED MANAGEMENT}

The problem of drinking water scarcity is growing day by day. One of the main reasons for this is the lack of planning and management of water resources. In agriculture dependant country like India, water plays key role in development of economic growth.

Uncertainty in rainfall and poor socio-economic condition of the farmers prevent them from making heavy investments in agriculture. To save the crops from drought during rainy season and to meet the water needs of the post-rainy season crop, farmers resort to groundwater exploitation resulting in recession of groundwater levels due to inadequate groundwater recharging facilities.

Watershed management arrests the soil erosion, reclaims vast tracts of eroded lands, improves soil moisture, harvests rainwater in small ponds or tanks, reduces floods, recharges groundwater and revives greenery. In due course it restores rainfall, revives healthy climate, regenerates soil, rejuvenates green foliage and revives environment. Further it renders the rural population self sustaining in food, fat, fiber, firewood, fodder, fruit, health and hygiene. As a result dependence of poor reduces, their farm produce increases and per capita income improves resulting in overall economic growth of the rural poor. For that, socioeconomic characterization (baseline survey) is important. Information generated through baseline survey provides knowledge about existing and potential production constraints, and propose potential areas for targeting technology transfer for sustainable development.

\section{SOCIO ECONOMIC SURVEY}

In order to understand the present position of Kaneri village in regard to various human social and Infrastructural aspects, a baseline survey based on questionnaire is carried out. This exercise was done with the objective of collecting information on developments/ changes that have taken place in the Kaneri village. We use following questionnaire:

1. Name:

2. Address:

3. Occupation:

4. Annual income:

5. Other family members, their occupation and education:

6. Migration of any family member, if yes, why?

7. Village population:

8. Own farm? If yes, how much?

9. Own wells? Own bore wells?

10. No. of bore wells in village:

11. Own animals? How many?

12. Drinking water sources?

13. Crop grown in the farm:

14. Major problem in the village:

15. Farm water resources:

A door to door visit of our students for getting filled this questionnaire made easy for us to have the proper information. We got the following information:

1. Occupation: farming

2. annual income (average): Rs.56971/-

3. Total population: 4909

4. Total animals: 1099

5. Total cultivated land: $661 \mathrm{Ha}$

6. Public wells: 6 and private wells: 111

7. No. of primary schools: 1

8. No. of secondary schools: 1 , 
9. Government Dispensary: 1

10. Development works: Road(Zillha parishad and Gram Panchayat)

11. Trees: Karvand, Mango, Teak, Neem, Subabul, Jambhul, Bel, Karanj, etc.

12. Crop grown: Groundnut, rice, Jawar and soyabean

13. Watershed Area: 965.94 Ha.

Due to this questionnaire, an excellent relationship was developed between villagers and us.

\section{PROBLEM IN THE AREA}

According to socio-economic survey, following problems were observed:

- Lack of water supplies in summer season

- All people are dependant only on farming.

- Agricultural production in only one season

- The land available for each family is very less (i.e. averagely 1.8 acres).

- To satisfy annual food requirements they need to take a crop thrice a year. But due to non-availability of water from February to May and also uncertainty in arrival of monsoon they are unable to take crop thrice a year and at present they take it only twice a year. This has led to low per capita income of people and hence poverty in the village.

- Low income levels hence low living standards

- There is significant slope with intense rains resulting in high degree of erosion.

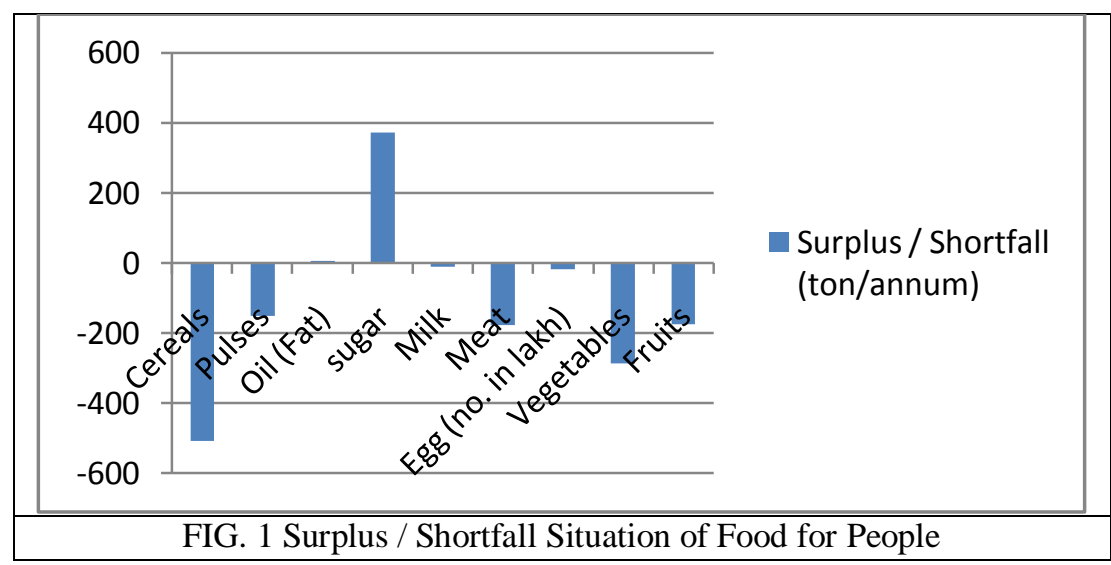

So to satisfy above mentioned needs, the watershed management is essential for Kaneri Village.

\section{Climatic CONDITION}

Tropical humid climate with good monsoon rainfall (avg. annual rainfall 973mm) in June to September, pleasant winters with $27^{\circ} \mathrm{C}$ to $30^{\circ} \mathrm{C}$. temp., tolerable summers with bright sunshine for 150 days. Good rainfall yet scarcity of water due to lack of bunds and boundary cultivation, negligence of rainwater harvesting and total lack of watershed approach for better crop product.

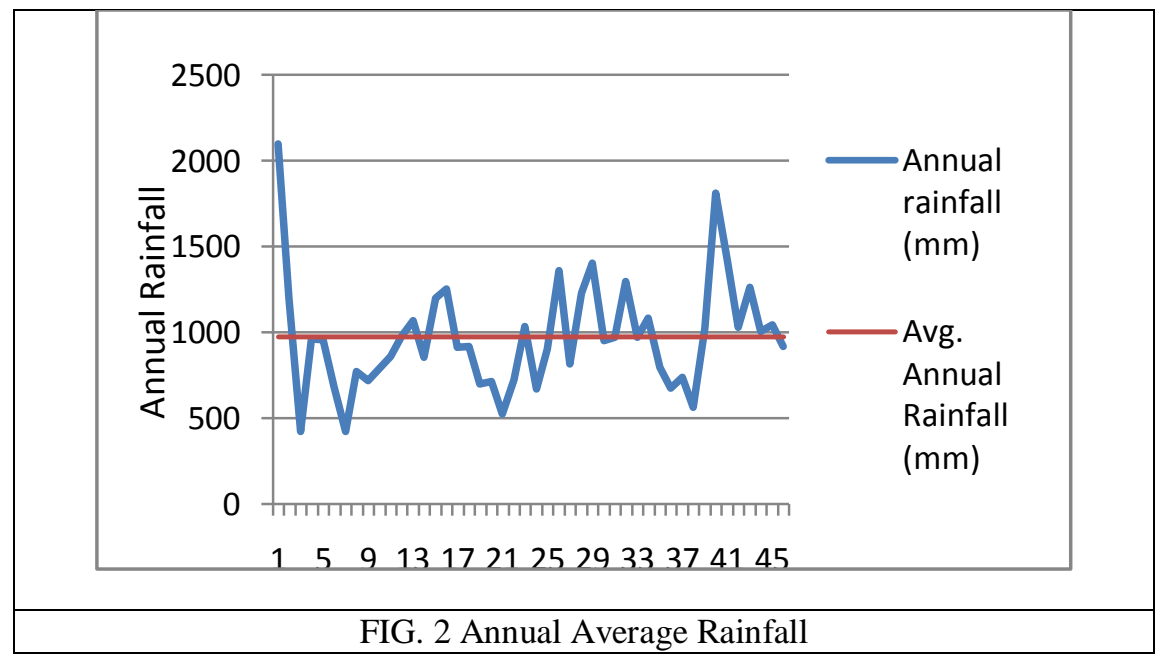




\section{WATER BUDGETING}

Before recommending water conservation measures it is necessary to evaluate runoff potential of the watershed. Basic formula is used for runoff calculation of Kaneri watershed.

a) Rainwater on the watershed = Area of watershed (sq.m) $\mathrm{x}$ Rainfall

$$
\begin{aligned}
& =975.94 \times 10000 \times 0.937 \\
& =94.96 \text { M.Cu.m. }
\end{aligned}
$$

b) Evapotranspiration $\quad=(30 \%)$ of Precipitation

$$
\begin{aligned}
& =0.3 \times 94.96 \\
& =28.49 \text { M.Cu.m. }
\end{aligned}
$$

c) Groundwater recharge $=$ Area of watershed (sq.m) $x$ Avg.fluctuation $\times$ Specific yield

$$
\begin{aligned}
& =975.94 \text { x } 10000 \times 1.5 \times 0.15 \\
& =21.96 \text { M.Cu.m. }
\end{aligned}
$$

d) Surface storage = Pond area $\mathrm{x}$ Avg. depth

$=94.86 \times 10000 \times 3.0 \mathrm{~m}$

$$
=28.45 \text { M.Cu.m. }
$$

e) Runoff $\quad=$ Precipitation - Basin recharge - Groundwater recharge - Evapotranspiration

$$
\begin{aligned}
& =(94.96-21.96-28.45-28.49) \text { M.Cu.m. } \\
& =16.06 \text { M.Cu.m. }
\end{aligned}
$$

Maximum water should be retained for checking erosive velocities and improving the moisture conditions. Land survey and subsurface investigations were carried out to know the drainage pattern.

\section{Solutions}

Contour survey and soil investigation is carried out to know the drainage pattern and soil characteristics of watershed area. Through that following structures were proposed for watershed management:

- Farm ponds - are small water harvesting structures used for collecting and storing runoff water. Farm ponds are constructed with varying size and may fulfill several farm needs such as supply of the water to crops for protective irrigation, fish production etc. this is help to increase income from crop production.

- Farm terracing- helps in soil conservation and holding runoff water on the terraced area for longer durations, leading to increased infiltration and ground water recharge.

- Contour trenches- are rainwater harvesting structures, which are constructed on hill slopes as well as on degraded and barren waste lands. They can be constructed in both high and low rainfall areas. The trenches are interrupted and are constructed along the contours.

- Gully plug - is one of the simple methods of soil and water conservation. These are small structures constructed with rubble masonry or concrete put in series one below the other from top to bottom of the depression. To prevent erosion, barriers or plugs of different types of material are put across the gully, at certain intervals.

- Check dams-These are weir structures provided in stream in initial stretch to check the gradient and surface runoff velocity. Along with these measures, some simple techniques are to be used.

- Cropping pattern -Generally, farmers in the Kaneri village uses sole cropping pattern. There is necessary to change this pattern and uses intercropping pattern. As per discussion with agriculture officer the suggestions are given as pulse crops and vegetable crops inter cropping with cereal crops $50 \%-50 \%$ in proportion 2:1 and 3:1 respectively. Cereal crops and pulse crops intercropping with oil crops 50\% $-50 \%$ in proportion with 1:1 and 2:1 respectively. Fallow land main properly by two times cutting grass and also on production of grass by bund cultivation nearly $3 \mathrm{Ha}(5 \%$ of cultivated land) increases green fodder up to $50 \%$ more. Cultivated land use changes shown in following table 1.

\subsection{POSSIBLE IMPACTS}

a) After construction of these structures, 11.35 M.cum. (71\% of runoff) water to be recharged.

b) The table 1 shows that near about $90 \%$ of cereal and pulse crop area and $280 \%$ vegetable crop area is increase. This gives benefit that near about $80 \%$ increase in crop production.

c) There is satisfying requirement of village people. Also by inter-treading of crop production there is increase in income village people from agricultural activity.

d) Also from increase in crop production, bund cultivation and proper maintaining the fallow land there is increase in cattle food as concentrate $50 \%$, dry fodder $50 \%$ and green fodder $50 \%$. This satisfies the cattle feed.

e) There is also increase in milk production by $10 \%-25 \%$ due to dry and green fodder as per discussion with veterinary officer. Also increases immunity of milch animals due to concentrates and green fodder. By selling the milk and inter-treading of cattle feed there is increase in income from non agricultural activity. 
TABLE 1 Possible Increase in Cultivated Land Use

\begin{tabular}{|c|c|c|c|c|}
\hline $\begin{array}{l}\text { Actual land } \\
\text { use (Ha) }\end{array}$ & $\begin{array}{c}\text { Suggested } \\
\text { intercropping pattern }\end{array}$ & $\begin{array}{c}\text { Change in land } \\
\text { use (Ha) }\end{array}$ & $\begin{array}{l}\text { Total change in } \\
\text { land use (Ha) }\end{array}$ & $\begin{array}{l}\text { \% Increase } \\
\text { in land use }\end{array}$ \\
\hline \multirow{2}{*}{$\begin{array}{c}160.7 \\
\text { (Cereal crop) }\end{array}$} & $\begin{array}{c}\text { cereal + pulse } \\
2: 1\end{array}$ & \multirow{2}{*}{$\begin{array}{c}160.7 \text { (Cereal) } \\
37.6 \text { (Pulse) } \\
\text { 25.1(Vegetables) }\end{array}$} & \multirow{2}{*}{$\begin{array}{c}305.6 \\
\text { (Cereal crop) }\end{array}$} & \multirow{2}{*}{$90 \%$} \\
\hline & $\begin{array}{c}\text { cereal + vegetable } \\
3: 1 \\
\end{array}$ & & & \\
\hline \multirow{2}{*}{$\begin{array}{c}105 \\
\text { (Pulse crop) }\end{array}$} & $\begin{array}{c}\text { pulse + cereal } \\
1: 2\end{array}$ & \multirow{2}{*}{$\begin{array}{c}26.2 \text { (Cereal) } \\
105 \text { (Pulse) } \\
17.5 \text { (Vegetables) }\end{array}$} & \multirow{2}{*}{$\begin{array}{c}201.9 \\
\text { (Pulse crop) }\end{array}$} & \multirow{2}{*}{$92 \%$} \\
\hline & $\begin{array}{c}\text { pulse }+ \text { vegetable } \\
3: 1\end{array}$ & & & \\
\hline \multirow{2}{*}{$\begin{array}{c}237.4 \\
\text { (Oil crop) }\end{array}$} & $\begin{array}{c}\text { oil crop + cereal } \\
1: 1 \\
\end{array}$ & \multirow{2}{*}{$\begin{array}{c}237.4 \text { (Oil crop) } \\
118.7 \text { (Cereal) } \\
59.3 \text { (Pulse) }\end{array}$} & \multirow{2}{*}{$\begin{array}{c}237.4 \\
\text { (Oil crop) }\end{array}$} & \multirow{2}{*}{--- } \\
\hline & $\begin{array}{l}\text { oil crop + pulse } \\
2: 1\end{array}$ & & & \\
\hline $\begin{array}{c}15 \\
\text { (vegetable) }\end{array}$ & --- & 15 (Vegetable) & $\begin{array}{c}57.6 \\
\text { (vegetable) }\end{array}$ & $280 \%$ \\
\hline
\end{tabular}

\section{EFFECTIVENESS OF WATERSHED MANAGEMENT- CASE STUDY}

\subsection{BEFORE - AFTER CONCEPT}

The year 2011-12 is taken as the position to explain 'Before watershed management work' and the year 2012-13 is taken as the position to explain 'After watershed management work'. This concept is used on a farmer which belongs to small farmer in Kaneri village.

TABLE2 Profile of Farmer

\begin{tabular}{|l|l|}
\hline \multicolumn{1}{|c|}{ Features } & \multicolumn{1}{c|}{ Details } \\
\hline Name & Mr. Yashwant Patil \\
\hline Age & 58 years \\
\hline Family members (No.) & 04 \\
\hline Land holding & 2 Ha. (rainfed) \\
\hline House & Semi-pacca \\
\hline
\end{tabular}

\subsection{APPLIED WATERSHED MANAGEMENT TECHNIQUE}

After discussion with him and site visualizing, there is found that land slope is $2 \%$ to $10 \%$. There is constructed that watershed management technique on $0.25 \mathrm{Ha}$. The most structures are constructed in the month of May 2012 which includes farm pond, gully plug, small earthen bund and contour trenching.

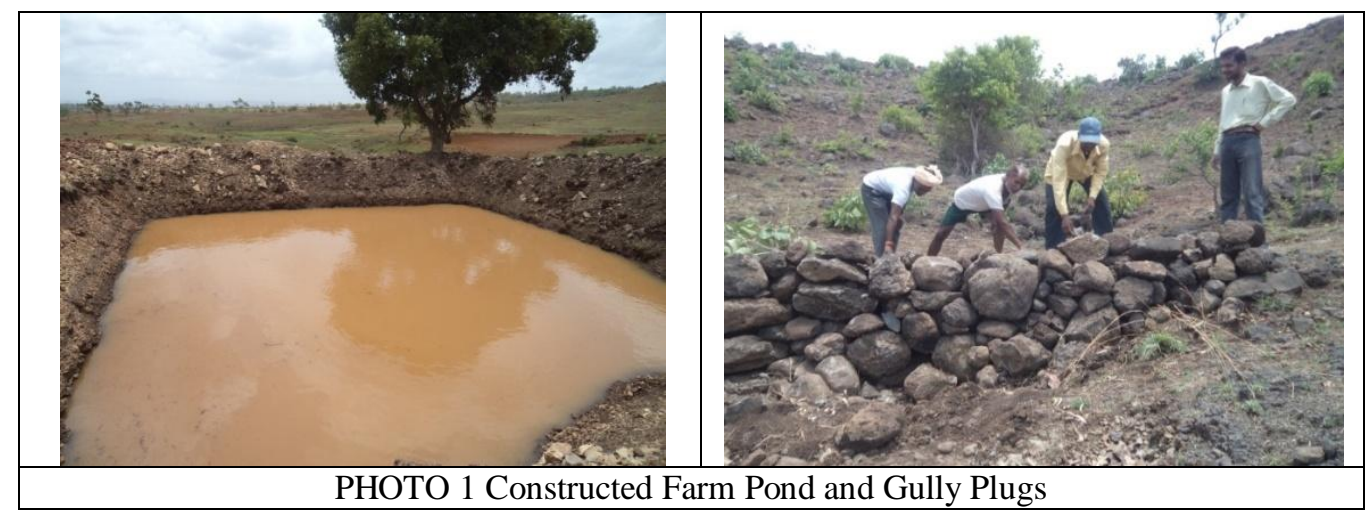




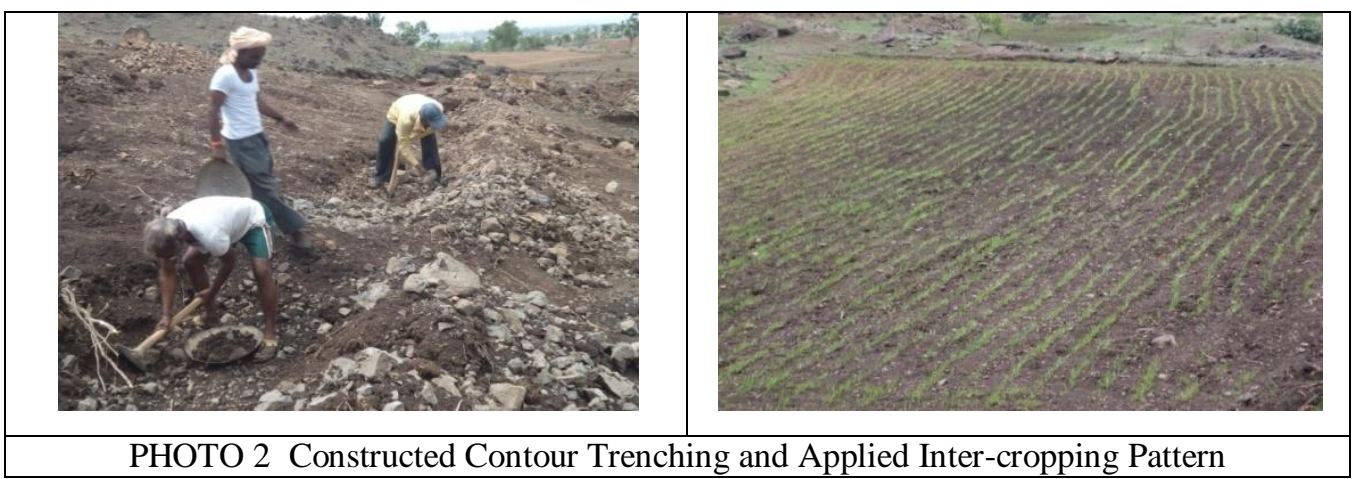

The main crop production from this farm is Rice and Groundnut. The intercropping pattern is applied which are for kharif season Groundnut and Jawar in proportion with 1:1 and Corn and Tur in proportion with 2:1. Also for rabbi season Jawar as sole crop. Rainfall in year 2012 is only $510 \mathrm{~mm}$. Table 3 shows the cost construction and quantity of water sorted by structures.

TABLE 3 Result of Constructed Watershed management Technique

\begin{tabular}{|l|c|c|}
\hline \multicolumn{1}{|c|}{ Recharge Structure } & Water Recharged & Cost of Construction \\
\hline Farm Pond $(15 \mathrm{mX} 15 \mathrm{mX} 3 \mathrm{~m})$ & $1836 \mathrm{Cu} . \mathrm{m}$. & \multirow{2}{*}{ Rs. 35,000/- only } \\
\cline { 1 - 2 } Contour Trenching & $1224 \mathrm{Cu} . \mathrm{m}$. & \\
\cline { 1 - 2 } Gully Plug and Earthen Bunds & $3060 \mathrm{Cu} . \mathrm{m}$. & \\
\cline { 1 - 2 } Total Recharge of Water & & \\
\hline
\end{tabular}

\subsection{IMPACTS OF WATERSHED MANAGEMENT}

Data from respondent the impact of watershed management, there is considerable improvement in the irrigation status. In the year 2011-12 the land is rainfed which changes into irrigated land in the year 2012-13 after watershed management work. Table 4 shows area of different crops before and after watershed management. The table 5 shows increase in production.

TABLE 4 Area under Different Crops - Before and After Watershed Management (Total Area - 2 Ha.)

\begin{tabular}{|l|c|c|c|c|}
\hline \multirow{2}{*}{ Crops } & \multicolumn{2}{|c|}{ Before Watershed Management } & \multicolumn{2}{l|}{ After watershed Management } \\
\cline { 2 - 5 } & Area (Ha.) & \% & Area (Ha.) & \% \\
\hline Jawar & 0.3 & 15.0 & 1.0 & 50.0 \\
\hline Corn & 0.0 & 0.0 & 0.3 & 15.0 \\
\hline Tur & 0.0 & 0.0 & 0.3 & 15.0 \\
\hline Rice & 0.4 & 20.0 & 0.4 & 20.0 \\
\hline Groundnut & 0.8 & 40.0 & 0.8 & 40.0 \\
\hline Fallow land & 0.5 & 25.0 & 0.35 & 17.5 \\
\hline $\begin{array}{l}\text { Area under Watershed } \\
\text { Management technique }\end{array}$ & 0.0 & 0.0 & 0.25 & 12.5 \\
\hline
\end{tabular}

TABLE 5 Crop Production - Before and After Watershed Management

\begin{tabular}{|c|c|c|}
\hline Crops & $\begin{array}{c}\text { Quantity (quintal)-Before } \\
\text { Watershed Management }\end{array}$ & $\begin{array}{c}\text { Quantity (quintal)-After watershed } \\
\text { Management }\end{array}$ \\
\hline Jawar & 3.75 & 6.50 \\
\hline Corn & - & 2.00 \\
\hline Tur & - & 1.50 \\
\hline Rice & 4.50 & 3.50 \\
\hline Groundnut & 6.75 & 7.25 \\
\hline
\end{tabular}

For calculating per capita income, the value of each crop is considered according to current market price at the time of study 'before' and 'after' situation. Total income is calculated without considering expenditure. The table 6 shows status of per capita income of the farmer. It is interesting to note that before 
implementation of watershed management technique, per capita income is Rs. 18928 which rise to Rs. 19806 due to impact of watershed management

TABLE 6 Per Capita Income - Before and After Watershed Management

\begin{tabular}{|l|c|c|}
\hline \multicolumn{1}{|c|}{ Description } & $\begin{array}{c}\text { Before Watershed } \\
\text { Management }\end{array}$ & $\begin{array}{c}\text { After watershed } \\
\text { Management }\end{array}$ \\
\hline Total Income (Rs.) & 75712.00 & 79225.00 \\
\hline Family Member (No.) & 04 & 04 \\
\hline Per Capita Income (Rs.) & 18928.00 & 19806.00 \\
\hline
\end{tabular}

\section{CONCLUSION}

Through the application of watershed management options, there is $71 \%$ of water stored out of total runoff i.e. 11.03 M.Cum. that means satisfy all requirement of water by watershed area. And near about $90 \%$ of cereal and pulse crop area and $280 \%$ vegetable crop area is increase. This gives benefit that near about $80 \%$ increase in crop production. There is satisfying requirement of village people. Also by inter-treading of crop production there is increase in income village people from agricultural activity

Through the case study, actual implementation of watershed management options such as farm pond, gully plugs, contour trenching there is found that $3060 \mathrm{cum}$. Means there is water available for irrigation to farmer form his own land after watershed management options. Also after implementation of intercropping pattern, there is also found that change in total crop production from farmers land is 15 ton per annum before watershed management to 20.75 ton per annum after watershed management. Finally, it is found that after implementation of watershed management technique, per capita of farmers family, increases by Rs. 878 $(4.64 \%)$.

Watershed management can bring about transformation of Kaneri village with increased per capita income and certain other measures like developing agro based industries, tourism centre (Village is famous for wax musium), naturopathy etc. by utilizing the available natural resources in best possible manner. Watershed management for Kaneri village will render the people self sustaining. This will also help to solve the present problem of overcrowding of the cities. Thus, finally conclude that, economical development of village people possible through watershed management.

\section{REFERENCES}

[1] B. A. Shiferaw, R. V. Reddy, S. P. Wani and G. D. Nageswara Rao, 'Watershed management and farmer conservation investments in the semi-arid tropics of India: Analysis of determinants of resource use decisions and land productivity benefits', Working Paper Series no. 16, Patancheru, Andhra Pradesh, India: International Crops Research Institute for the Semi-Arid Tropics, $2003,1-24$.

[2] B. Mishra, 'A successful case of participatory watershed management at Ralegansiddhi village in district Ahmadnagar, Maharastra, India', Case studies of people's participation in watershed management in Asia (GCP/RAS/161/NET), FAO Corporate Document Repository, 1996.

[3] B. Sada Siva, 'Experience and case study on impact evaluation of watershed development: farm pond - a means for poverty reduction', Seminar on watershed development, DHAN foundation, 2006.

[4] B. Shivarudrappa, 'Farm pond for sustainable livelihood - a case study of Pampanur', Seminar on rural development, CRIDA, Hyderabad, April 2009.

[5] K. H. Anantha, S. P. Wani and T. K. Sreedevi, 'Baseline socio-economic characterization of watersheds', Workshop on best-bet option for integrated watershed management, International Crops Research Institute for the Semi-Arid Tropics (ICRISAT) Patancheru, Andhra Pradesh, India, July 2007.

[6] Mrs. V. A. Swami, Dr. Mrs. S. S. Kulkarni, 'Watershed management - a means of sustainable development - a case study, International Journal of Engineering Science and Technology', Volume 3, March 2011, 2105-2112.

[7] Mrs. V. A. Swami, Dr. Mrs. S. S. Kulkarni, 'Model watershed management plan for Shivapur village', International Journal of Engineering Science and Technology, Volume 2, December 2011, 1-5.

[8] Rajeshwari Desai, 'An economic analysis of rain water harvesting, structures - a case study of farm-ponds', Thesis Report, Department Of Agricultural Economics, College Of Agriculture, Dharwad, University Of Agricultural Sciences, Dharwad, August 2005, 1-98.

[9] Shgaji Phand and H. P. S. Arya, 'Adarsh Gaon Yojana- way towards Gandhi's dream village: self-sufficient, prosperous and peaceful', Journal of rural development', NIRD, Hyderabad, Volume 26, No. (2), 2006, 207-225.

[10] S. P. Wani and Kaushal K. Garg, 'Watershed Management Concept and Principles', Workshop on best-bet option for integrated watershed management, International Crops Research Institute for the Semi-Arid Tropics (ICRISAT) Patancheru, Andhra Pradesh, India, 2010, 1-10.

[11] S. P. Wani and Y. S. Ramakrishna, 'Sustainable management of rainwater through integrated watershed approaches for improved rural livelihoods', Seminar on sustainable management of rainwater, 2005.

[12] Tesfaye Habtamu, 'Assessment of sustainable watershed management approach case study lenche dima, tsegur eyesus and dijjil watershed', A project paper presented to the Faculty of the Graduate School of Cornell University, May 2011, 1-118. 


\section{AUTHORS}

1. Mr. Vishal P. Kumbhar has appearing M.E. (Construction and Management) in K.E. Society's Rajarambapu Institute of Technology, Sakharale, Dist- Sangli (India). He has complete his B.E. from Government College of Engineering, Karad, DistSatara.

2. Mrs. Vidula A. Swami is currently working as an Associate professor in the Department of Civil Engineering, K IT's College of Engineering, Kolhapur (India). She has got her post graduate degree from College of Engineering, Pune (Poona University) and currently registered for Ph.D. under Shivaji University, Kolhapur. She has to her credit 24 years of service in teaching. She has published a number of articles in leading International journals. She has participated and presented in a number of national and international conferences and seminars. Her area of interest in the field of research includes Watershed Management.

3. Dr. Sushama S. Kulkarni is currently working as Director-Principal at Rajarambapu Institute of Technology, Sakharale, Sangli (India). She has received her B.E. from VRCE, Nagpur and M.E Degree and Ph.D. in Civil Engineering from Shivaji University, Kolhapur. . She has to her credit 24 years of service in teaching. She has published a number of papers in leading international journals. She has participated and presented in a number of national and international conference and seminars. Her area of interest in the field of research includes Total Quality Management. 